\title{
New records of Libellula pulchella (Odonata: Libellulidae) and Phyllogomphoides albrighti (Odonata: Gomphidae) from the Cuatro Ciénegas Basin, Coahuila, Mexico
}

\section{Nuevos registros de Libellula pulchella (Odonata: Libellulidae) y Phyllogomphoides albrighti (Odonata: Gomphidae) para el valle de Cuatro Ciénegas, Coahuila, México}

\author{
Enrique González-Soriano ${ }^{1 凶}$, Marysol Trujano-Ortega ${ }^{2}$, Arturo Contreras-Arquieta ${ }^{3}$ and Uri Omar \\ García-Vázquez ${ }^{2}$ \\ ${ }^{1}$ Departamento de Zoología, Instituto de Biología, Universidad Nacional Autónoma de México. Apartado postal 70-153, 04510 México D. F., México. \\ ${ }^{2}$ Museo de Zoología, Facultad de Ciencias, Universidad Nacional Autónoma de México. Apartado postal 90300, 04510 México D. F., México. \\ ${ }^{3}$ Acuario y Herpetario W. L. Minckley. Pte. Carranza 104 Nte., 27640 Cuatro Ciénegas de Carranza, Coahuila, México. \\ \esoriano@ibunam2.ibiologia.unam.mx
}

\begin{abstract}
The first records of Libellula pulchella and Phyllogomphoides albrighti from Coahuila are reported. These records extend the known geographic range of Libellula pulchella south of Texas and Phyllogomphoides albrighti west of Nuevo León. The specimens were collected in the Cuatro Ciénegas Basin, one of the most biologically interesting areas for the study of aquatic insects.
\end{abstract}

Key words: geographic distribution, Libellula pulchella, Phyllogomphoides albrighti, Coahuila, Mexico.

Resumen. Se presentan los primeros registros de Libellula pulchella y Phyllogomphoides albrighti para Coahuila. Ambas especies extienden su distribución geográfica conocida más allá del sur del estado de Texas y más allá del oeste de Nuevo León, respectivamente. Los ejemplares fueron recolectados en la región del valle de Cuatro Ciénegas, uno de los lugares más interesantes para el estudio biológico de insectos con hábitos acuáticos en algún estadio.

Palabras clave: distribución geográfica, Libellula pulchella, Phyllogomphoides albrighti, Coahuila, México.

With regard to the odonate fauna, the state of Coahuila was for many years one of the least studied among the Mexican states bordering the United States (Behrstock, 2009). Until 1996 only 21 species had been recorded for the state (Paulson and González-Soriano, 1994; González-Soriano and Novelo-Gutiérrez, 1996). Nevertheless, in recent years some publications and occasional collections increased the knowledge of the distribution and diversity of Odonata within the state to 29 species (Dinger et al., 2005; González-Soriano and Novelo-Gutiérrez, 2007; Behrstock, 2009). Finally, in a recent publication, Behrstock (2009) estimated 65 species of Odonata fauna for Coahuila and included a new record for the country.

Within the state, the Cuatro Ciénegas Basin is one of the most biologically interesting areas for the study of aquatic life. It is an isolated arid area situated in a $40 \mathrm{~km}$

Recibido: 23 enero 2012; aceptado: 29 marzo 2012 wide depression in the center of the state. It is located 75 $\mathrm{km} \mathrm{W}$ of Monclova and covers a surface area of ca. 2176 $\mathrm{km}^{2}$. This site has nearly 200 ponds filled by subterranean water, which flows from the vicinity of Sierra de San Marcos (Behrstock, 2009). The vegetation of Cuatro Ciénegas Basin was described by Pinkava (1978) as halophilic (Nymphaea ampla, Juncus torreyi, Phragmites australis, Ruppia maritima, and Spartina spartinae), and the entire basin is composed of grasslands, sedges and marshes, gypsum dune assemblages, desert scrub, and chaparral.

In a study of aquatic invertebrates, Dinger et al. (2005) estimated 24 species of Odonata within the area. However, this approximation must be taken cautiously because the taxonomic identifications were made with larval material and may contain some errors (Behrstock, 2009).

During recent fieldwork in the Cuatro Ciénegas Basin, two species of dragonflies caught our attention, Libellula pulchella Drury, and Phyllogomphoides albrighti (Needham). A total of 67 species are now recorded for 
the state of Coahuila (Behrstock, 2009; this study). All specimens collected were deposited in the Colección Nacional de Insectos del Instituto de Biología, UNAM (CNIN-IBUNAM).

Libellula pulchella Drury, 1770

Libellula is a holartic genus with species occurring in America, Europe, and Asia. Particularly, L. pulchella (Twelve-spotted Skimmer) is a species widely distributed in the United States north to the southern border of Canada. Bailowitz and Danforth (2008) published recently the first report of this species for Mexico for the state of Sonora. It is a medium-sized dragonfly (length $52-57 \mathrm{~mm}$ ), with conspicuously spotted wings. Males of this species are very active flyers and rest little during hours of sunshine. They fly several feet above the water. Females often oviposit unattended, usually over submerged vegetation in bays and shoals, striking the water at points far apart (Needham et al., 2000). On September 30, 2011, we collected a male specimen of L. pulchella at Poza Tío Cándido, Rancho Orozco (26 $52^{\circ}$ '18.3” N, $102^{\circ} 05^{\prime} 16.8^{\prime \prime}$ $\mathrm{W} ; 740 \mathrm{~m}$ elev.) (Fig. 1). The vegetation in Rancho Orozco is composed of desert scrub with small patches of halophilic and gypsophilic vegetation. In areas near the ponds this vegetation has been replaced by common reed (Phragmites sp.), and Casuarina and Taxodium trees (Pinkava, 1980). This locality represents the first record of this species for the state, and the record extends the known geographic range of this species slightly south from known localities in southern Texas (Abbott, 2005).
Phyllogomphoides albrighti (Needham, 1950)

Phyllogomphoides is a neotropical genus with two species ( $P$. albrighti and P. stigmatus) present in the southern United States. Phyllogomphoides albrighti (Five-striped Leaftail) is a large dragonfly (length 60-63 $\mathrm{mm}$ ) recorded from New Mexico and Texas (Abbott, 2005). The habitat for this species is streams and rivers with swift currents and cobble or muddy bottoms, with riparian vegetation. It is said to perch on vegetation, fences, or other structures one meter or so above the ground (Abbott, 2005). Nevertheless, the first author collected specimens perched on grasses, several meters away from the water at the Río Coy, San Luis Potosí. On 27 September 2011, we collected two males of this species flying above Poza Las Teclas, Antiguos Mineros del Norte $\left(26^{\circ} 46^{\prime} 57.5^{\prime \prime} \mathrm{N}, 102^{\circ} 00^{\prime} 27.2^{\prime \prime} \mathrm{W} ; 725 \mathrm{~m}\right.$ elev.) (Fig. 1). The habitat in Antiguos Mineros is characterized by the presence of large areas of Prosopis glandulosa. In wetter areas, the original vegetation has been replaced by crops of corn, beans, cotton, and other exotic species such as Acacia sp., Taxodium sp. and Arundo donax. In Mexico, P. albrighti was previously recorded for the states of Nuevo León, San Luis Potosí, Tamaulipas, and Veracruz (González-Soriano and Novelo-Gutiérrez, 2007; González-Soriano and Novelo-Gutiérrez, 2011). The discovery of $P$. albrighti in Cuatro Ciénegas Basin represents a new record for the state of Coahuila.

Support for fieldwork was provided by the Theodore Roosevelt Memorial Fund (American Museum of Natural

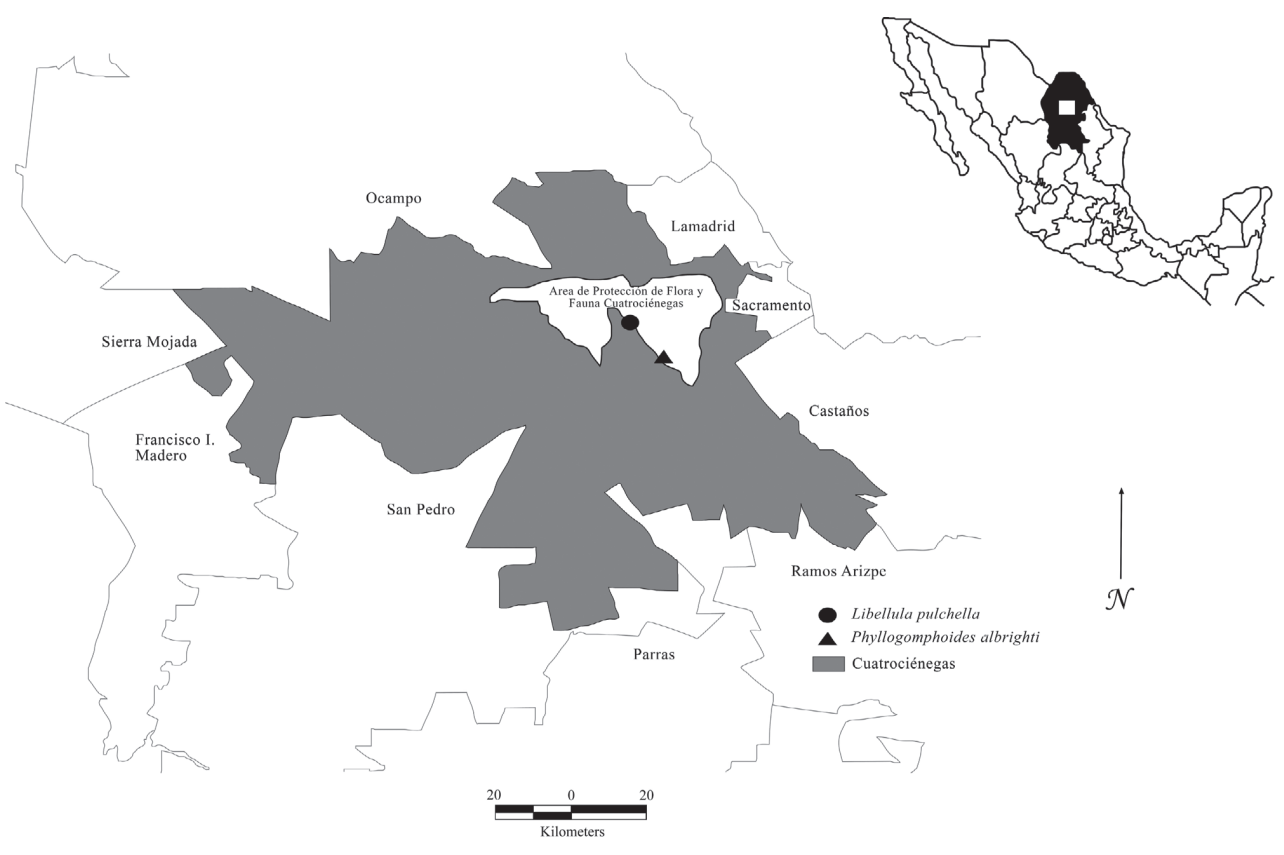

Figure 1. Localities of Libellula pulchella and Phyllogomphoides albrighti from the Cuatro Ciénegas Basin, Coahuila, Mexico. 
History) to MTO and UOGV; the Dirección General de Apoyo al Personal Académico, Universidad Nacional Autónoma de México (PAPIIT IN224009); CONACyT (083237); and the WWF-Alianza Carlos Slim (L039). We thank PRONATURA A. C., DESUVALLE A.C., and CONANP for their assistance with the fieldwork. We also thank Omar Ávalos Hernández for his comments.

\section{Literature cited}

Abbott, J. C. 2005. Dragonflies and damselflies of Texas and the South-Central United States: Texas, Louisiana, Arkansas, Oklahoma, and New Mexico. Princeton University Press, Princeton and Oxford. 344 p.

Bailowitz, R., and D. Danforth. 2008. Libellula pulchella (Twelvespotted Skimmer) without black wingtips. Argia 20:10-11.

Behrstock, R. A. 2009. An updated list of the Odonata of Coahuila, México, including forty-one new state records and the first Mexican occurrence of Libellula composita (Hagen). Bulletin of American Odonatology 11:1-7.

Dinger, E. C., A. E. Cohen, D. A. Hendrickson and J. C. Marks. 2005. Aquatic invertebrates of Cuatro Ciénegas, Coahuila, México, natives and exotics. The Southwestern Naturalist 50:237-281.

González-Soriano, E. and R. Novelo-Gutiérrez. 1996. Odonata. In Biodiversidad, biogeografía y taxonomía de artrópodos de
México: hacia una síntesis de su conocimiento, J. LlorenteBousquets, A. N. García-Aldrete and E. González-Soriano (eds.). UNAM, México, D. F. p. 147-167.

González-Soriano, E. and R. Novelo-Gutiérrez. 2007. Odonata of México: revisited. In Odonata: Biology of Dragonflies, B. K. Tyagi (ed.). Sci Publ. (India) p. 105-136.

González-Soriano, E. and R. Novelo-Gutiérrez. 2011. Libélulas (Insecta:Odonata). In La Biodiversidad en Veracruz: estudio de estado,V. Hernández-Ortiz (ed.). Comisión Nacional para el Conocimiento y Uso de la Biodiversidad (Conabio), Gobierno del Estado de Veracruz, Universidad Veracruzana, Instituto de Ecología, A. C., México. p. 295-306.

Needham, J., M. Westfall and M. May. 2000. Dragonflies of North America. Scientific Publishers. Gainesville. 939 p.

Paulson, D. R and E. González-Soriano. 1994. The Odonata of Mexico by state. University of Puget Sound, available on: http:/www.pugetsound.edu/academics/academic-resources/ slater-museum/biodiversity-resources/dragonflies/mexicanodonata/ (last access: 13.XII.2011).

Pinkava, D. J. 1979. Vegetation and flora of the Bolson of the Cuatro Ciénegas region, Coahuila, México, I. Boletín de la Sociedad Botánica de México 38:35-44.

Pinkava, D. J. 1980. Vegetation and flora of the Bolson of Cuatro Cienegas region, Coahuila, Mexico, II (Casuarinaceae to Loasaceae). Boletín de la Sociedad Botánica de México 39:107-127. 